\title{
EPISTEMOLOGY OF BASIC CONCEPTS OF SPIRITUAL AND PHYSICAL THAHARAH: Analysis of The Benefits of Ablution Spiritually and Physically
}

\author{
Meirison ${ }^{1)}$, Fadhilah Insani ${ }^{2}$, Zahara Andini ${ }^{3)}$, \\ 1,2,3) UIN Imam Bonjol Padang \\ e-mail: meirison.a@gmail.com ${ }^{1)}$, fadhilahinsani00@ gmail.com ${ }^{2)}$, \\ zaharaandini@gmail.com $^{3)}$
}

\begin{abstract}
This article aims to explain the purpose of purification in various forms. Purification outwardly and inwardly will be obtained when following the rules given by the Qur'an and Hadith. Ablution (thaharah) is one of the legal conditions in performing Salat. When we start performing an act of worship such as Salat, many of us are not right or wrong when taking ablution or sometimes after removing many unclean impurities. I did a literature study with a descriptive analysis approach and found that three ways can be pure: bathing, ablution, and tayammum. The tools used for bathing and ablution are water and for tayammum using soil (dust). As we know, Tayammum can only be done when there is no water and in a state of pain. Purification also removes not only the contaminated feces but also the inner. In purifying, using absolute water or using soil (dust) must meet certain conditions. By doing purification according to the provisions of Rasulullah, then we will get external and internal purity. After doing a lot of research on the benefits of ablution, let a Muslim improve the way of doing ablution according to the rules exemplified by the Prophet PBUH.
\end{abstract}

Keywords: Epidemiology, Concept, Spiritual, Physical, Thaharah 


\section{A. INTRODUCTION}

We know that the main elements that must be fulfilled to meet Shalat worship requirements, such as Prayer and so on, he did not start by purifying. Purifying is the main requirement in establishing Prayer or tawaaf in the temple. Consecrated becomes the main gateway in worshipping Allah SWT. Wudu, bathing in junub and tayammum, is a sacred way that Allah has explained in the Qur'an clearly.

The writer did library research with descriptive approach of method and analyzes the benefits of purification in general and ablution in particular. Scientific analysis is also obtained in performing this ablution ibada which supports the belief in the benefits of wudu not only for the spiritual but also for the body. In this paper, the author examines the book Wahbah Zuhaili fiqh, which talks about purifying from various kinds of good dirt. After that, the author also reviewed a book entitled Islamic education by Zakiyah Darajat, which describes all kinds of worship, including purification as part of Islamic education, which purifies the outer and inner. Previous research obtained is ablution is a ritual washing performed by Muslim and it is part of compulsory activities to ensure cleanliness before the Muslim perform prayer it has been recorded in the Holy Book's of Quran. In general, ablution followed by washing on particular body, based on Quran, Sunnah and the Scholars consensus, the ablution ritual which they have a few rules and manner when performing the ritual. not only until there is purity and ablution well will bring physical benefits that have been medically proven.

\section{B. DISCUSSIONS}

\section{The Meaning of Fiqh and Usul Fiqh}

\section{Understanding, Legal Basis, Assortment, and Wisdom of Thaharah}

1. The Meaning of Thaharah

Taharah is derived from the Arabic word خهر-يهـ - خهرة: which means holy. Taharah means purifying from various impurities or clean and purified from impurities or uncleanness that can be seen and unclean, which can not be seen as disgrace and sin. According to az-Zuhaili, taharah means "cleanliness" when I am said to purify clothes, then actually, I am cleaning as clothes. According to another sense, taharah 
means to be clean from impurities, either visible or invisible. And Allah taharah is all-performing, all-important. ${ }^{1}$

Al-Imam ibn Ibn Ibn al-Daa'imah al-Maqdisi said udamah that taharah has four stages, namely; First, purify born of hadats, unclean, feces, Secondly, purify limbs from sin and sin, Third, purify the heart of despicable morals and bad qualities, Fourth, purify the hearts of others besides Allah.

Prof. Dr. Zakiyah Darajat divides taharah into birth and bathing; purifying from bathin is purified and repent to cleanse yourself from sin. The way to wash it is by repenting sincerely of all sins and sin, from the impurities of doubt, hatred, spite, cheating, deceit, ria the way is to act openly, love goodness, tawadhu' and only expect a ridha from Allah for all his deeds. ${ }^{2}$ While birth hygiene is clean from feces and hadas, the way to clean feces is to remove such impurities from a place of worship, clothing, and a person's body. And when you cleanse the hadeeth, it is by wudoo' and bathing. ${ }^{3}$

Water that can be used for purifying is rainwater, seawater, water that has been used for purifying (mustakmal water), and water mixed with something holy (such as mixed soap) and still as initially, unchanged from its form as water. As for the water that has been mixed with something unclean and changes the smell, taste, and color, then the water can not be used to purify. However, if it does not change the smell, taste, and color, the water can still cleanse. The remaining water used to be drunk is sacred, except for the remaining water of the drink of pigs and dogs, then the water is unclean. ${ }^{4}$

${ }^{1}$ Wahba az-Zuhailī, al-Fiqh al-islāmī wa-adillatuhū: aš-šāmil li- 'l-adilla aš-šar '̌yya wa-' 'l-ārā al-madhabìya wa-ahamm an-nazarīyāt al-fiqhīya wa-tahqūq al-ahāà̄it an-

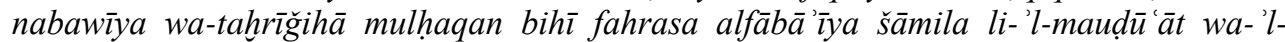
masā' 'il al-fiqhīya. Ğuz' 11: al-Fahāris al- 'āmma: fahrasa alfabā'yia šāmila li- 'l-āyāt wa'l-ahādīt wa- 'l-mauḍū 'ât al-fiqhīya, Nachdr. der vierten verb. Ausg. (Dimašq Bairūt: Dār alfikr, 2002), 77.

${ }^{2}$ Meirison Meirison and M. Harir Muzakki, "Implementing The Spirit of Jihad in Sufism," Jurnal THEOLOGIA 31, no. 1 (November 6, 2020): 1.

${ }^{3}$ Zakiah Daradjat and Indonesia, eds., Ilmu Pendidikan Islam, Cet. 2. (Jakarta: Diterbitkan atas kerjasama Penerbit Bumi Aksara, Jakarta dengan Direktorat Jenderal Pembinaan Kelembagaan Agama Islam, Departemen Agama, 1992), 36.

${ }^{4}$ Meirison Alizar Sali, Desmadi Saharuddin, and Rosdialena Rosdialena, "Takhrij Fikih Dan Permasalahan Kontemporer," Al-Istinbath : Jurnal Hukum Islam 5, no. 1 (May 9, 2020): 51. 
2. Taharah Legal Basis

Abdul Khaliq Hasan suggested that one of the foundations of taharah law is surah Al-Furqan verse $11 \mathrm{Al}$

It means; It is He who sends the wind as a bearer of glad tidings, near before his mercy, and we send down water from the sky clear water.

Wahbah az-Zuhaili in al-Munir's commentary explains, the meaning of this verse is that Allah sends down holy water as a purifying tool for both body, clothing, and others. Because the word thahur means something used for taharah (divine), as the phrase wudoo' is used for wudoo'. ${ }^{5}$

He said, "O my people! Say what it means; And clean your garments, and all impurities are idolatrous.

He en-sy'ed has commanded humankind to cleanse their garments and all that is in the heavens and all in the earth. Cleaning clothes can be interpreted by cleaning clothes born and inner soul. ${ }^{6}$ So with the above verse, Allah says that cleaning from birth and inner soul must be combined because the two must be connected and interconnected. $^{7}$

Prophet Muhammad PBUH said:

It means; Take care of cleanliness wherever possible, because Allah Heaven builds Islam above cleanliness, and will not enter heaven unless the people are clean (H.R At-Thabrani)

Cleanliness or purifying becomes the primary medium of approaching God because God loves those who purify themselves, as Allah says in surah al-Baqarah verse 222

It means; Surely Allah loves those who repent and purify themselves.

${ }^{5}$ Zuhailīi, al-Fiqh al-islāmī wa-adillatuhū, 21/1.

${ }^{6}$ Iredho Fani Reza, "Wudu as Islamic Psychotherapy to Improve Sleep Quality in Young Women," Journal An-Nafs: Kajian Penelitian Psikologi 5, no. 1 (June 1, 2020): 6475.

${ }^{7}$ Abdel Samie Mohamed Al-Anees, "The Prophetic Tradition on Wudu' (Ablution) at Anger: A Tradition Study,” مجلة كلبة الثريعة و الدراسات الإسلامية "2017), accessed January 27, 2021, http://journals.qu.edu.qa/index.php/sharia/article/view/64. 
3. Kinds of Thaharah

a. Thaharah hakiki

Taharah is meant to be related to the cleanliness of the body, clothing, and place of Prayer from unclean. It can be said that taharah is, in fact, the release of a person from uncleanly. A praying man who wears clothes that have blood stains or urine is not valid Shalatnya. For he is not free from insanity.

Taharah can be obtained by eliminating impurities that stick either to the body, clothes, or in place to perform rituals of worship; the way varies depending on the level of impurity. If the uncleanness is mild, then simply sprinkle water, but if the uncleanness is heavy, it should be washed with water seven times and one of them with soil. If the uncleanness is sanctified, it middle then purified by washing it with ordinary water, it loses its unclean color and loses its cloudy smell and uncleanness loss.

b. Taharah Hukmi

A person who does not cancel his Shalat wudoo' maybe that physically no impurities have befallen him, taharah. Still, he must re-oblige by doing wudoo' if he wants to perform certain services such as Prayer, tawaf, and others.

And he who comes out of the semen, Even though he had cleaned it clean, and changed his clothes with a new one, he was not said to be holy from the great hadeeth until he had finished bathing. ${ }^{8}$

So Taharah Hukmi is ritual purity, physically there is no dirt attached, but it is as if he is not holy to perform ritual worship. Taharah Hukmi is done by wudoo' or Janabah bath. atau

4. The Wisdom of Thaharah

The wisdom and benefits of taharah are many, not only related to ritual worship but also many understanding and benefits that are more profound and widespread. Broadly the services of taharah include physical benefits and benefits for physical taharah. Each can be described as follows: ${ }^{9}$

${ }^{8}$ Sali, Saharuddin, and Rosdialena, “Takhrij Fikih Dan Permasalahan Kontemporer." ${ }^{9}$ Ibid. 
a. Physical benefits

First, washing the whole body and all the existing segments can increase freshness and spirit, eliminate fatigue and lethargy, and perform Prayer correctly, solemnly, and feel supervised by Allah SWT.

Second, purifying is a healthy physical harmony because feces usually carry many diseases and plagues. Muslims are very decent. To be the most physically healthy person, far from disease, Islam has taught them to keep their bodies clean, clothes, and shelter. ${ }^{10}$

Third. Purifying means glorifying a Muslim, his family, and his community.

b. Benefits of Ukhrawi for physical taharah

First, everyone who has a religious passion agrees to do this task, regardless of the rich or poor, the villagers, or the city.

And Allah is all-15, all-wise.

Third, by seeing a believer carry out Allah's command, doing the deeds of Salih seeking pleasure, doing the knowledge correctly by the existing Sharia will cultivate faith, give birth to the sense of supervised God. So that every time he does, taharah intending to seek the Allah SWT pleasure. ${ }^{11}$

Fourth. All Muslims' agreement to do taharah in the same way and cause wherever they are and whatever the number and the understanding of the people in doing business are because the intertwined inter-heartedness is more compact in doing business will be more substantial their unity. While the essence of taharah is complete for the whole body, is:

1) And Allah is All-Ing, All-17, All-1777. For example, it is a shower on the feast day and a Friday shower.

${ }^{10}$ Husnul Fatarib Meirison, "Al-Hajat As The Basis of Contemporary Ijtihad" 17, no. 1 (2020): 105-121.

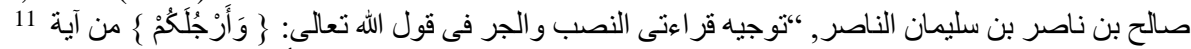

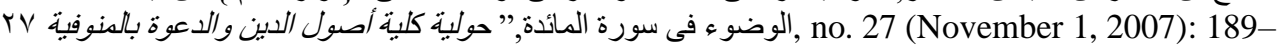
205. 
2) There can be no doubt that the relationship between body hygiene and peace of mind is very close to a new body and a vibrant soul. For example, if the body is cleansed after Mubasyarah (intercourse), return the spirit to freshness and lose the body's laziness.

3) Turning the soul from the state of Bahimiah to Malakiyah, the balance of the soul with the orgasm of Jimak", attracts the soul to the Bahimiyah-an nature, when it happens, so we immediately bathe (taharah). Our souls will return to Malakiyyah's nature.

4) We were purifying ourselves from hadats and uncleanness signals that we should always cleanse our souls from sin and all evil.

The wisdom and benefits of taharah give us the knowledge of how vital taharah is, not only just worship but also its intent. Several things are the purpose of the sharia taharah, including: ${ }^{12}$

a. To purify yourself from impurities in the form of hadas and unclean.

b. As a condition of the valid Prayer and worship of a servant.

Taharah has its wisdom, namely as a caretaker and selfcleanser of various impurities and disturbing things in a servant's worship activities. A servant who has always loved to purify him will have the virtues bestowed by God in the Hereafter. Taharah also helps a servant to prepare before performing services to God.

For example, a man who prays he is facing Allah; therefore, wudu makes that the servant's mind can be ready to worship and escape the worldly busyness. It is obligatory to do wudu before Prayer because wudu is a means to calm and relieve the mind from the worldly busyness to perform Sholat. ${ }^{13}$

${ }^{12}$ Muḥammad Ibn-Maḥmūd Akmal-ad-Dīn al-Bābartī, Burhān-ad-Dīn 'Alī-Ibn-AbīBakr al-Marḡīnān̄̄, and Abū-Mạ̣rūs 'Amr Ibn-Mạ̣rūs, al- 'Ināya šarḥ al-hidāya: wa-huwa šarh 'ala 'l-Hidāya šarh bidāyat al-mubtadī fì furū' al-fiqh al-ḥanafì li-Burhān-ad-Dīn 'AlīIbn-Abī-Bakr al-Marḡiñ̄̄n̄̄ (Bairūt: Dār al-Kutub al- 'Ilmīya, 2007), 21.

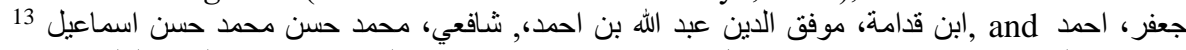

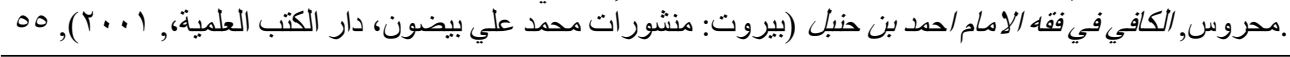




\section{The Sacred Ordinance of Hadas}

Cleaning is born of Hadas, unclean, and excess (fudhulat) in the body.

1. Cleansing limbs from sins.

2. We are cleansing the heart of despicable behavior.

3. Cleansing the heart from other than God

The special sanctified ordinances are as follows:

1. Purified from Hadas

The way of purifying from Hadas can be done in three ways: ${ }^{14}$

a. Ablution

Wudu according to language, means clean. And whoever of you washes an individual body with purifying water, he will not be able to do so, and he will not be able to do so in the Word of Allah SWT in Surah Al Maidah verse 6.

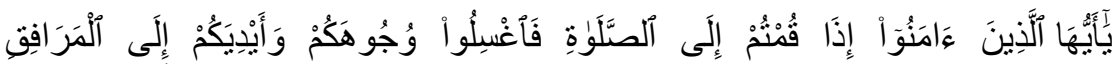

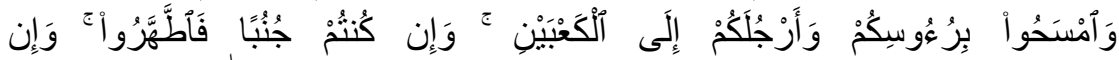

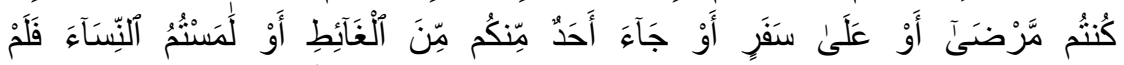

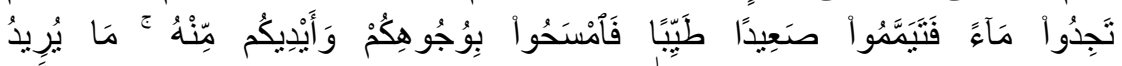

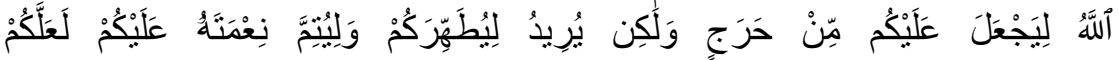

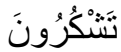

It means: "O believers, when you want to do prayer, wash your face, your hands to your elbows, and sweep your head and wash your feet to your ankles." (QS Al Maidah:6)

And here are the ordinances:

1.) Reading basmalah

2.) Wash both palms

3.) Gargling

4.) Wash face three times

5.) Wash hands to elbows three times starting from the right

6.) Rub the head three times from the tip of the face to the nape

7.) Wipe the ear three times, the outside with the thumb and the inside with the index finger

8.) Wash both feet to the ankles three times

${ }^{14}$ S. A. Prathapar et al., "Design, Construction and Evaluation of an Ablution Water Treatment Unit in Oman: A Case Study," International Journal of Environmental Studies 63, no. 3 (June 2006): 283-292. 
b. Bath

Bathing is washing the body with water by watering the water to the body or soaking the body in a river, lake, lake, sea, pond, or bathtub. Humans need a bath to remove dead odors, dust, dirt, and skin cells. Bathing is useful to maintain health, maintain cleanliness, and maintain a neat appearance. After bathing, humans usually feel fresh, clean, and relaxed. ${ }^{15}$

And here are the ordinances:

1.) Take water and wash hands up to three times

2.) Cleaning with the left hand

3.) Clean all unclean that stick to the body

4.) Take whudo' as you wish to pray

5.) Start bathing by splashing your head three times

6.) Splashing the right and left bodies three times

7.) Make sure water flows into the folds of the skin folds as well as the base of the hair

c. Tayammum

Tayammum is a heavenly bed with dust, and there is no water or obstruction. Tayammum, according to the term, is to Weatherholt soil or dust to the face and both hands to the elbow by qualifying get along well as a substitute for wudu or obligatory bathing due to the absence of water or prohibited use of water due to pain. ${ }^{16}$ The word of Allah SWT in Surah An Nisa verse 43.

It means: "And if you are sick or on a traveler or come from a place of defecate, do tayammum or you have touched a woman, then you have no water, then leave with a good land, sweep your face and your hands, verily Allah is Forgiving, Forgiving." (Q.S. An Nisa:43)

Tayammum is a substitute for ablution. And if a man has prayed with tayammum, he finds water, so it is not obligatory to repeat it

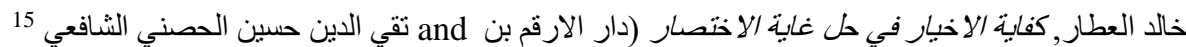

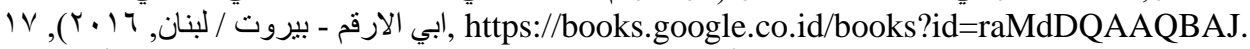

جعفر، احمد and ,ابن قدامة، موفق الدين عبد الله بن احمد،, شافعي، محمد حسن محمد حسن اسماعيل 16 محروس, الكافي في فقه الامام احمد بن حنبل مديل 
even though the prayer time is still there. And here are the ordinances: ${ }^{17}$

1.) Prepare dusty soil or clean dust

2.) Patting both palms to the ground with a single punch

3.) Rubbing both palms all over the face is accompanied by tayammum intent in the heart or spoken in a slow voice

4.) Sweeping the back of the right palm with the left hand so vice versa

5.) All swipes are right when wiping the back of the palm and face is done with just one swipe

6.) Part of the hand that is wiped up to the wrist only is not the same as wudu washed up to the elbow.

2. Purified from unclean

a. Mild uncleanness (mukhaffafah)

Najis Mukhaffafah is unclean in the urine of a baby boy who is not yet two years old and has not eaten other than milk from his mother (breast milk). ${ }^{18}$ How to clean light uncleanness, e.g., clothes exposed to a baby boy's pee, by merely splashing water only, but this does not apply if the baby has started eating other than breast milk intake. The Messenger of Allah (peace and blessings of Allaah be upon him) said:

The girl's urine was washed, while the boy's urine was sprinkled (H.R Abu Daud, An-Nasa'I,)

b. Unclean (mutawasithah) Medium

Najis mutawassithah is a type of moderate-level unclean. Among the unclean people of mutawassithah are other unclean, namely those who are not unclean mughalladhah and mukhaffafah. That includes the unclean Mutawassithah, namely urine, moles, madzi water, pus, anything that comes out of the

${ }^{17}$ Akmal-ad-Dīn al-Bābartī, Margīinānī, and Ibn-Maḥrūs, al- Ināya šarḥ al-hidāya, 57.

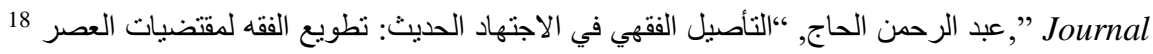
of Islamic Ethics 3, no. 1-2 (December 27, 2019): 64-89. 
stomach, carcasses (other than humans, fish, and locusts), blood (other than the liver and spleen), and others. ${ }^{19}$

Goods that are unclean mutawasithah (medium) can be holy by washing the origin of unclean properties such as smell, taste, and color are lost. Based on the hadeeth narrated by mutafaq alaih, from Anas ibn Maalik R.A, he said; A badawi Arab urinated in one part of the mosque, so the people wanted to scold him. But the Prophet (PBUH) forbade them. When he finished urinating, the Prophet Muhammad SAW ordered to flush his urine with a water bucket.

How to purify unclean mutawasithah is explained in a story in the hadeeth, when Asma bint Abu Bakr, he said, a woman once came to the Prophet Muhammad SAW, then he said; Some of us have menstruating blood, what do we have to $d o$ ? He said, "Remove the blood from the garment, then remove the feces that are left with water, and wash it. Then pray with him (H.R Muslim 225)

c. Najis Ainiyah

Uncleanness is tangible and scarred and has a taste or smell. This unclean can be cleaned by washing the water once or three times until the unclean disappears. ${ }^{20}$

d. Najis Hukmiyah

Uncleanness does not appear to be objects, such as urinary marks, dry ingestion, etc. It can be purified by water in the affected part. $^{21}$

e. Najis Mughallazhah

Mughalladhah's type of uncleanness is severe unclean because it is necessary to treat it specifically to clean it or purify it. What

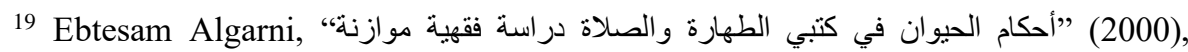
accessed January 27, 2021, http://rgdoi.net/10.13140/RG.2.2.17202.81609.

20 Muhammad Ibn-Aḥmad as-Sarahs̄ī, Abū-'Abdallāh Muhammad Ḥasan

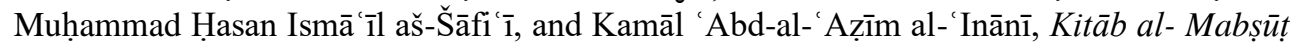
fi 'l-fiqh al-ḥanafì (Bairūt: Dār al-Kutub al-'Ilmīya, 2009), 17.

${ }^{21}$ Al-Anees, "The Prophetic Tradition on Wudu' (Ablution) at Anger." 
belongs to the unclean Mughalladhah is the uncleanness of dogs and pigs, along with the will of one of the services. ${ }^{22}$

Goods affected by Mughallazhah licks such as dog licks must be washed seven times, and one of them uses water mixed with soil. It can also be by rubbing the ground with a direct movement on the dog's licked hands. After that, it is freshly rinsed with water. ${ }^{23}$

Based on the hadeeth narrated by Imam Al-Bukhaari Said and the Muslim imam, from Abu Hurayrah, he said that the Messenger of Allaah (peace and blessings of Allaah be upon him) said: Howto purify the vessels between you when the dog is licked purified seven times and initially with the land (Muttafaq 'Alaih).

\section{Tayammum Ordinances and Their Readings}

1. Tayammum Ordinances

a. Prepare dusty soil or clean dust

b. Patting both palms to the ground with a single punch

c. Rubbing both palms all over the face is accompanied by tayammum intent in the heart or spoken in a slow voice

d. Sweeping the back of the right palm with the left hand so vice versa

e. All swipes are right when wiping the back of the palm and face is done with just one swipe

f. Part of the hand that is wiped up to the wrist only is not the same as wudoo is washed up to the elbow.

2. Tayammum Readings

"I intend to pray because of Shalat of Allah."

\section{Ruling on chicken manure, goats, and animal urine that can be consumed in meat}

What is the best way to get a good night's work?

${ }^{22}$ Akmal-ad-Dīn al-Bābartī, Maròīnānī, and Ibn-Maḥrūs, al- 'Ināya šarḥ al-hidāya, 211.

${ }^{23}$ Sarahssī, Šāfi '̄i, and 'Inānī, Kitāb al-Mabșūt fi 'l-fiqh al-ḥanafì, 77. 
There are pieces of evidence that need to be considered as follows: ${ }^{24}$

First: There was a hadeeth from Anas when a swarm of people came from 'Ukel or from 'Uraynah, mentioned in the hadeeth,

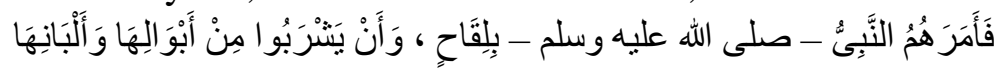

"The prophet PBUH told them to drink urine and milk from dairy camels." (HR. Bukhari, no. 233)

If camel milk is drinkable, then the urine is the same, and it is mentioned simultaneously in one context. We know that camels are among the animals that are halal to eat. This hadeeth is proof from scholars who declare the sacred feces or urine of animals that are halal to eat. ${ }^{25}$

Second, there is also a hadith from the Prophet PBUH that he was asked about the law of Prayer in the goat cage,

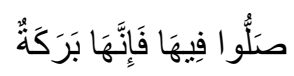

"Please pray in the goat's enclosure; there bring blessings (tranquility)." (H.R. Abu Dawood, 184 and Ahmad, 4:288. Shaykh al-Albaani said that the hadeeth is Saheeh.

Imam Shafii added goats bring tranquility and blessings. When someone prays in the goat's cage, the animal does not disturb and does not break the Prayer of the One who Prays. The hadith shows that it is permissible to pray in a goat's enclosure and not to pray in a camel cage.

This is mentioned in 'Aun al-Ma'bud, 1:232. ${ }^{26}$

The hadeeth above are also, so the evidence is not unclean goat dung, because the one who prays in the goat cage is still allowed. But in the cage is not separated from the dirt. Goats are halal animals to eat. So from this, the scholars generalize that halal animals' feces are sacred, not unclean. ${ }^{27}$

${ }^{24}$ Mehterhan Furkani, “Cemal-i Halvetî El-Aksaraŷ̂’nin Esraru’l-Vudû Adlı Eserinin Tahkik ve İncelenmesi,” Mütefekkir 4, no. 7 (June 30, 2017): 173-195.

${ }^{25}$ Sarahsīi, Šāfi 'ī, and 'Inānī, Kitāb al-Mabșūt fi 'l-fiqh al-hanafì, 57.

26 'Awn al-ma 'būd sharh Sunan

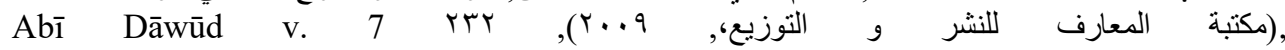
https://books.google.co.id/books?id=DoJuAQAACAAJ1.

27 Sherifa Mostafa M Sabra, "Ablution (Wudu) Health Benefits (HBs) through Comparison Nasal-Cavity (NC) Bacterial-Content (BC) with Gold-Standard (GS) at HighAltitude (HA) Area, Taif, KSA," Journal of Applied Biotechnology \& Bioengineering 5, no. 6 (November 16, 2018), accessed January 27, 2021, https://medcraveonline.com/JABB/ablution-wudu-health-benefits-hbs-through- 
Third: The rule that must be understood, "The law of origin of all things is sacred.". Imam Asy-Syaukani stated,

"The law of origin of all things is sacred." 28

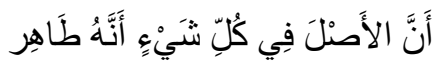

When Imam Asy Syaukani wanted to show that not all animal excrement is unclean, he added a critical explanation, "If it is said that something is unclean, then this means burdening the servant with a law. Therefore, the original law, a servant, is free from burdens, and a servant is not burdened with anything that is still likely (muhtamal) unclean or not until there is proof stating clearly that it is unclean." 29

Fourth: Maliki scholars, Hambali, and one of the Shafii sect's opinions, state that the Mazhab feces of animals that are halal to eat are sacred. The evidence used is the evidence mentioned above. As for the Hanafiah scholars, the Shafii sect's view, all the feces of animals are unclean either halal animals ate or animals that are not halal. In conclusion, the law of origin of all things is sacred. ${ }^{30}$ The feces of the animals that are forbidden to eat are unclean, while halal animals' feces are sacred.

\section{The Benefits of following The sunnah of the Prophet in Purification}

one of the scientific proofs of the Sunnah of the Prophet Muhammad on defecating is defecating in a squatting position. Squatting can accommodate a full adult body weight, improve the quality of bowel movements, and help prevent several health problems related to bowel pressure, anal cancer, hemorrhoids and many other diseases. ${ }^{31}$ Not only that, even ablution is said to have a good effect on the brain and up to the prevention of stroke.

comparison-nasalndashcavity-nc-bacterialndashcontent-bc-with-goldndashstandard-gs-athighndashaltitude-ha-area-taif-ksa.html.

20 سحمد بن علي/الثوكاني, الدراري المضية شرح الدرر البهية Dand-Kutub al-`Ilmiyah, 2003), 57, https://books.google.co.id/books?id=OH6DDwAAQBAJ.

${ }^{29}$ Ibid.

${ }^{30}$ Mufaizin Mufaizin, "Kearifan Syariat Dan Hikmah Dalam Puasa," Al-Insyiroh: Jurnal Studi Keislaman 2, no. 1 (March 16, 2018): 103-127.

31 interview with Ahmad Halim at Andalas University, April 16, 2018 about the virtues of defecating in a squatting state 


\section{CONCLUSION}

Etymological Fiqh is an in-depth knowledge or understanding of the purpose of a speech and deed. According to the terminology of Fiqh is the science that explains the laws of Sharia derived from detailed evidence. Fiqh, according to language, means understanding. Usul Fiqh is a rule used to formulate the sharia laws from the pieces of evidence.

In conclusion, the law of origin of all things is sacred. The feces of the animals that are forbidden to eat are unclean, while halal animals' feces are sacred. Eating weasel meat is halal. The fatwa is based on the rule that says that the original law of all things is permissible or lawful except the one stipulated by the other evidence. Meanwhile, weasel animals are not among the animals that are forbidden to be consumed.

The unlawful animals are consumed as explained in the Qur'an and hadith, among others. The carcasses of land animals, the blood of flowing animals, the pork, the animals that are slaughtered in the name other than Allah, the animals that are suffocated, beaten, fallen, horned, struck by beasts, and slaughtered for idols. Other animals that are forbidden to be consumed are ringed animals, such as tigers, wolves, lions, bears, dogs, and cats.

Then, birds with claws grip their prey, such as eagles, eagles, and owls. As the hadith reads, "Narrated by Ibn 'Abbaas, he said: The Messenger of Allaah (peace and blessings of Allaah be upon him) forbids every animal that has fangs from among the beasts and every and everyone that has claws from among the birds." (Hr Muslim). Also, animals or birds whose food is vultures are forbidden to be consumed. Then, nasty and disgusting animals, such as scorpions, insects, and lizards.

Then, animals that are also forbidden to be consumed are ordered to kill them, such as snakes, rats, and crows. Animals that are forbidden to kill them, such as swallows, frogs, ants, hud-hud, and bees, are also forbidden to be consumed, including all animals that endanger the health or make them sick. 


\section{BIBLIOGRAPHY}

Akmal-ad-Dīn al-Bābartī, Muḥammad Ibn-Maḥmūd, Burhān-ad-Dīn 'AlīIbn-Abī-Bakr al-Marḡinān̄̄, and Abū-Mahrūs 'Amr Ibn-Mahrūs. al'Ināya šarh al-hidāya: wa-huwa šarh 'ala 'l-Hidāya šarh bidāyat almubtadī fì furū' al-fiqh al-ḥanafì li-Burhān-ad-Dīn 'Alì-Ibn-Abì-Bakr al-Margìn̄̄n̄ì. Bairūt: Dār al-Kutub al- 'Ilmīya, 2007.

Al-Anees, Abdel Samie Mohamed. "The Prophetic Tradition on Wudu' (Ablution) at Anger: A Tradition Study.” مجلة كلبة الثريعة و الدراسات (2017). Accessed January 27, 2021. http://journals.qu.edu.qa/index.php/sharia/article/view/64.

Daradjat, Zakiah, and Indonesia, eds. Ilmu Pendidikan Islam. Cet. 2. Jakarta: Diterbitkan atas kerjasama Penerbit Bumi Aksara, Jakarta dengan Direktorat Jenderal Pembinaan Kelembagaan Agama Islam, Departemen Agama, 1992.

Ebtesam Algarni. “"أحكام الحيوان في كتبي الطهارة و الصلاة دراسة فقهية موازنة "2000). Accessed January 27, 2021. http://rgdoi.net/10.13140/RG.2.2.17202.81609.

Fani Reza, Iredho. "Wudu as Islamic Psychotherapy to Improve Sleep Quality in Young Women." Journal An-Nafs: Kajian Penelitian Psikologi 5, no. 1 (June 1, 2020): 64-75.

Furkani, Mehterhan. “Cemal-i Halvetî El-Aksarayî'nin Esraru'l-Vudû Adlı Eserinin Tahkik ve İncelenmesi.” Mütefekkir 4, no. 7 (June 30, 2017): 173-195.

M Sabra, Sherifa Mostafa. "Ablution (Wudu) Health Benefits (HBs) through Comparison Nasal-Cavity (NC) Bacterial-Content (BC) with GoldStandard (GS) at High-Altitude (HA) Area, Taif, KSA." Journal of Applied Biotechnology \& Bioengineering 5, no. 6 (November 16, 2018). Accessed January 27, 2021. https://medcraveonline.com/JABB/ablution-wudu-health-benefitshbs-through-comparison-nasalndashcavity-nc-bacterialndashcontentbc-with-goldndashstandard-gs-at-highndashaltitude-ha-area-taifksa.html.

Meirison, Husnul Fatarib. "Al-Hajat As The Basis of Contemporary Ijtihad" 17, no. 1 (2020): 105-121. 
Meirison, Meirison, and M. Harir Muzakki. "Implementing The Spirit of Jihad in Sufism." Jurnal THEOLOGIA 31, no. 1 (November 6, 2020): 1 .

Mufaizin, Mufaizin. "Kearifan Syariat Dan Hikmah Dalam Puasa." AlInsyiroh: Jurnal Studi Keislaman 2, no. 1 (March 16, 2018): 103-127.

Putra, M. K. B. (2015). Eksistensi Sistem Pesantren Salafiyah dalam Menghadapi Era Modern. Al-Insyiroh: Jurnal Studi Keislaman, 1(1), 87-104.

Prathapar, S. A., M. Ahmed, S. Al Adawi, and S. Al Sidiari. "Design, Construction and Evaluation of an Ablution Water Treatment Unit in Oman: A Case Study." International Journal of Environmental Studies 63, no. 3 (June 2006): 283-292.

Sali, Meirison Alizar, Desmadi Saharuddin, and Rosdialena Rosdialena. "Takhrij Fikih Dan Permasalahan Kontemporer." Al-Istinbath : Jurnal Hukum Islam 5, no. 1 (May 9, 2020): 51.

Sarahssī, Muḥammad Ibn-Aḥmad as-, Abū-'Abdallāh Muhammad Hasan

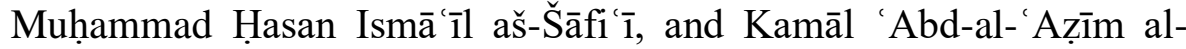
'Inānī. Kitāb al-Mabșūt fi 'l-fiqh al-ḥanafí. Bairūt: Dār al-Kutub al'Ilmìya, 2009.

Zuhailī̄, Wahba az-. al-Fiqh al-islāmī wa-adillatuhū: aš-šāmil li-'l-adilla aššar 'ìya wa-' '-ārā al-madhabìya wa-ahamm an-nazarīyāt al-fiqhīya

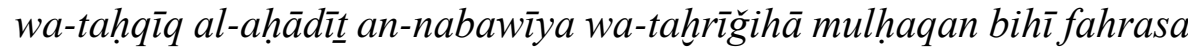
alfābā' '̀ya šāmila li- 'l-maudū 'ât wa- 'l-masā'il al-fiqhìya. Ğuz' 11: alFahāris al- 'āmma: fahrasa alfabā'ȳia šāmila li-'l-āyāt wa-'l-ahādīt wa-'l-maudū 'āt al-fiqhìya. Nachdr. der vierten verb. Ausg. Dimašq Bairūt: Dār al-fikr, 2002.

جعفر، and, ابن قدامة، موفق الدين عبد الله بن احمد،, شافعي، محمد حسن محمد حسن اسماعيل

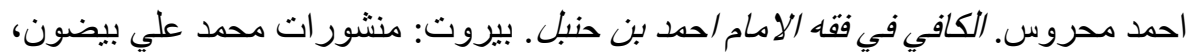

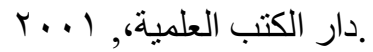

محمد بن علي/الثوكاني. الدراري المضية شرح الدرر البهية and البدري, سالم مصطفى البع. Dar alKutub al-'Ilmiyah, 2003. https://books.google.co.id/books?id=OH6DDwAAQBAJ.

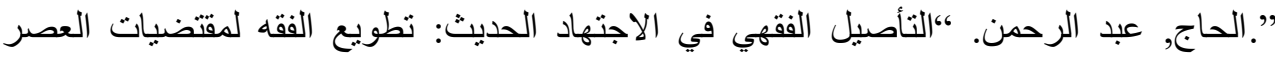
Journal of Islamic Ethics 3, no. 1-2 (December 27, 2019): 64-89. 


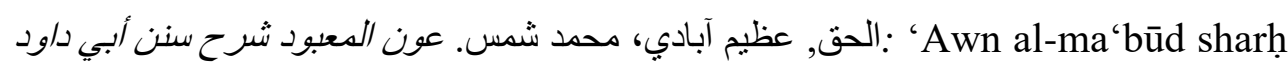

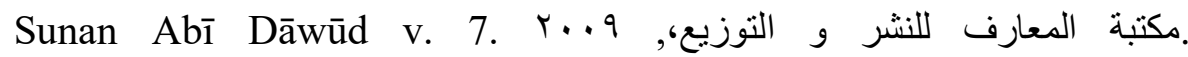
https://books.google.co.id/books?id=DoJuAQAACAAJ.

خالد العطار . كفابة الاخبار في حل غابة الاختصار . دار and الثافعي, تقي الدين حسين الحصني

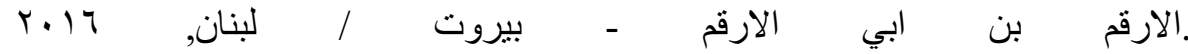
https://books.google.co.id/books?id=raMdDQAAQBAJ.

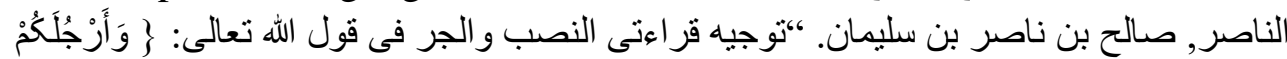

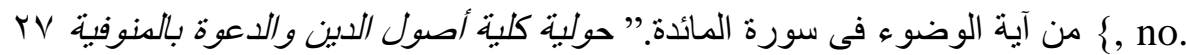
27 (November 1, 2007): 189-205. 